\title{
Supply Chain Management: How The Curricula Of The Top Ten Undergraduate Universities Meet The Practitioners' Knowledge Set
}

\author{
Saba Bahouth, University of Central Oklahoma, USA \\ David Hartmann, University of Central Oklahoma, USA \\ Geoff Willis, University of Central Oklahoma, USA
}

\begin{abstract}
The disciplines of logistics and supply chain management have the potential of having many areas of emphasis. Universities that have some kind of emphasis in this field have developed programs that depend on the need of potential employers and their own faculty mix. Several studies have previously looked at how universities deal with this field at the graduate level, mainly as part of their MBA program. In this study, the authors focus on the ten universities in the United States that have the leading undergraduate programs in supply chain management. They look at each of their curriculum in terms of courses and course content and see how each of these universities satisfies a previously established knowledge set for this field of study. They realize that there will most likely never be in the foreseeable future a well-structured and agreed upon common curriculum for teaching this particular subject matter. The intended audiences are businesses that are hiring new graduates and the universities that are looking to start a similar program.
\end{abstract}

Keywords: Curriculum; Supply Chain Management; Logistics; Undergraduate; Knowledge Set

\section{INTRODUCTION}

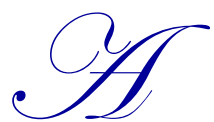

lthough logistics and supply chains have been crucial to success in operations ranging from military campaigns to circuses (Creveld, 1977; Mabert, 2010) for centuries, formalized academic programs are a relatively recent phenomenon. Indeed, recent publications (Croom et al., 2000) note some reluctance on the part of many academics to recognize supply chain management as an academic discipline. This is partly attributable to the organic development of many supply chain programs and potential for many areas of emphasis depending on the mix of faculty expertise and areas of interest by potential employers in the area.

\section{PREVIOUS WORK}

The wide variety of program designs owes to the development of this cross-disciplinary field from several different perspectives, among them operations management, operations research/management science, organizational behavior, strategic management, systems engineering, industrial organization, marketing, logistics, purchasing, and industrial engineering. Key concepts in supply chain management come from these disparate fields, but among the earliest research efforts to take a holistic approach to the supply chain field are works by Heckert and Miner (1940), Lewis (1956), and Forrester (1961). For a thorough review of diverse nature of the supply chain literature and founding disciplines, the reader is directed to Croom et al. (2000).

This plethora of founding departments has resulted in the need for cooperation across classical department lines within the college of business, in many cases extending to engineering colleges. It is somewhat ironic that a discipline that stresses the need for cooperation and collaboration among multiple players would at times suffer from 
lack of cooperation and different reward structures among the departments tasked with teaching this very subject. Morris (1997) is perhaps the first to identify a need for cross disciplinary cooperation in order to achieve a fully integrated supply chain management program. Closs and Stank (1999), Melnyk et al. (2000), Johnson and Pyke (2000) and Vollman et al. (2000) were quick to follow Morris with proposed curricula for supply chain management programs. These publications and an increased profile at academic conferences beginning in the late 1990s helped establish much of the content that is now commonly associated with supply chain management curricula. As the needs of industry have changed, so too has the collection of courses that appear in most programs (Hedge and Radovilsky, 2012).

Common criticisms of academic program designs in comparison to practitioners' stated needs are that coursework emphasizes theoretical models that are poorly understood or too difficult to apply (Clayson and Haley, 2005) and that academics are slow to recognize and respond to new approaches or lag practice; hence, their research efforts tend to be descriptive. Other studies (Visich and Khumawala, 2006) uncover the disconnect between university programs targeted at entry level or trainee positions for undergraduates or MBAs while practitioner studies tend to focus on upper management. Studies by Davis (1974, 1975), Green et al. (1977), Wild (1984), and Berry and Lancaster (1992) all identify a dissonance between the academic preference for quantitative techniques versus the practitioner preference for quantitative concepts. In addition, employers frequently complain that graduates are lacking in softer skills - oral and written communication (Hwarng, B. and Teo, C., 2001). In the Larson (2008) study, there was general agreement on the importance of more general managerial skills such as communication, computer skills, leadership, and relationship building.

Such criticism is not unique to the supply chain management discipline. A common lament exists among practitioners that academicians fail to identify and teach many important concepts regardless of discipline (Fleming, 2008). It is notable that even among supply chain professionals, there is significant disagreement regarding essential tools and topics in the area. A survey $(\mathrm{n}=2012)$ of the membership of the Purchasing Management Association Canada, conducted by Larson (2008), revealed stark contrasts in perspectives on the scope of the field and areas that should be emphasized while training professionals.

A number of studies have been conducted regarding curriculum design in the supply chain management field. These studies fall into two main categories - those that emphasize overall curriculum design and those that present a teaching tool that is used to teach a specific concept.

Ferrin et al. (2001) adopt a total quality management approach to develop and sustain curriculum in supply chain management. Gonzalez et al. (2008) apply quality function deployment to the problem of curriculum design. The voice of the customer entries in their house of quality matrix were gleaned from purchasing managers, plant managers, and logistics managers from companies that hire logistics and supply chain professionals. The authors applied a data reduction technique to identify a set of customer priorities that can be compared with the skills identified in Johnson and Pyke (2000). Among the universities included in the benchmarking section of this study is the University of Tennessee, a perennial member of the US News and World Report top ten in supply chain management.

Among studies advocating tools for SCM teaching are Huynh, M., and Chu, H. (2011), who advocate use of an open-source ERP package to teach supply chain management and business process integration. Corsi et al. (2006) present a real time supply chain simulation game for presenting supply chain principles. Their Global Supply Chain Game operates with a continuous clock and incorporates a computer element to fill roles of the environment, suppliers, markets and competing distribution centers. The oldest and best known supply chain simulation tool is The Beer Game, conceived by John Sterman (1989) and used to demonstrate system dynamics in a supply chain and the bullwhip effect.

\section{METHODOLOGY}

There is no shortage in published research on the content of the different MBA and undergraduate business academic programs, but the discipline of supply chain management - a relatively new academic discipline - has not been systematically studied at the undergraduate level. This study focuses on the undergraduate supply chain 
management program in ten leading universities in this field in the United States. The intent is to analyze the content of each of the ten programs, attempting to discover a common approach for teaching this subject matter. The intended audiences are hiring businesses, as well as universities, looking to start a similar program.

The list of the ten leading universities in supply chain management was derived from the annual ranking of U.S. News and World Report. A quick look at the U.S. News and World Report ranking shows that the same ten universities topped the list in the field of supply chain management for the last three years the survey was conducted (2012, 2013, and 2014 ranking). There have been some changes in the positions during these three years, but the population on that list remained the same.

The U.S. News and World Report states that "to be ranked in a certain specialty, an undergraduate business school may have either a program or course offerings in that subject area" (see Table 1). Such an approach opened the way to having some universities listed without having a complete undergraduate degree in Supply Chain Management. It was confirmed that two universities on the list - Massachusetts Institute of Technology and the University of Michigan-Ann Arbor - did not offer an undergraduate degree in Supply Chain Management and therefore were replaced with two other universities. Instead of using the universities that are ranked $11^{\text {th }}$ and $12^{\text {th }}$ on the U.S. News and World Report ranking, two universities from an alternative listing - Gartner Research list of the top supply chain undergraduate programs (see Table 1) - were included. The ranking criteria and the top ten ranking for both U.S. News and World Report and Gartner Research are shown in Table 1.

Table 1: Ranking Criteria And The Top Ten Ranking For Both U.S. News And World Report And Gartner Research US News and World Report (a)

\begin{tabular}{l} 
Ranking Criteria: \\
\hline Graduation and retention rate \\
Assessment by peers and counselors \\
Faculty resources \\
Student selectivity \\
Financial resources \\
Graduation and performance \\
Alumni giving \\
2014 Ranking: \\
Michigan State University \\
Massachusetts Institute of Technology \\
Arizona State University \\
Ohio State University \\
Pennsylvania State University \\
University of Tennessee \\
Carnegie Mellon University \\
University of Maryland \\
Purdue University \\
University of Michigan
\end{tabular}
Gartner Research (b)

\begin{tabular}{ll}
\multicolumn{1}{c}{ Gartner Research (b) } & \\
\hline \multicolumn{1}{c}{ Ranking Criteria: } & $20.0 \%$ \\
\hline Industry survey on recruiting spots & $20.0 \%$ \\
Internships and starting salary & $20.0 \%$ \\
Program size (students and faculty) & $40.0 \%$ \\
Program scope & \\
&
\end{tabular}

\begin{tabular}{l} 
2011 Ranking: \\
\hline Pennsylvania State University \\
Arizona State University tied with \\
Georgia Institute of Technology and \\
Rutgers University \\
Michigan State University \\
University of Texas/Austin \\
Ohio State University tied with \\
University of Wisconsin/Madison \\
Texas A\&M tied with \\
University of Tennessee
\end{tabular}

(a) U.S. News and World Report - Best Colleges, 2014 Edition, pp. 34-35

(b) ID Number: G00218965. Publication Date: 6 October 2011, page 2. (C) 2011 Gartner, Inc. and/or its Affiliates. All Rights Reserved.

After acquiring AMR Research in 2010, Gartner Research continued to publish its own list of the top supply chain management programs in the United States. Their latest 2011 ranking has Georgia Institute of Technology and Rutgers University both tied in second place with Arizona State University and second only to Pennsylvania State University. Since both Arizona State University and Pennsylvania State University are already among the top five on the U.S. News and World Report list, the two universities that do not have an undergraduate program were replaced with Georgia Institute of Technology and Rutgers University. The resulting list of the ten supply chain management programs researched in this paper, in alphabetical order, is: 


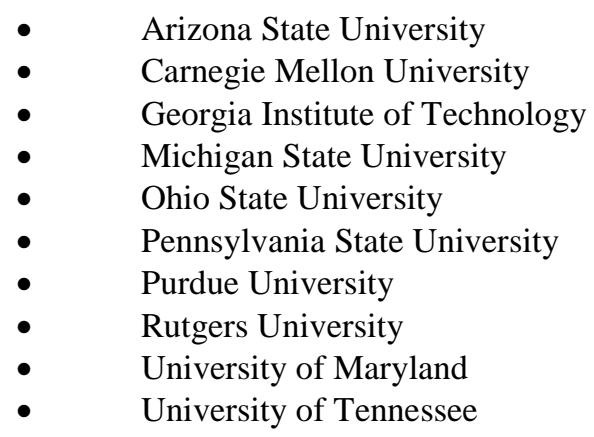

\section{DATA COLLECTION AND ANALYSIS}

The analysis proceeds as follows: first the program name, location and degree are considered. This is followed by an exploration of the common core business courses in the program, followed by the required and elective courses for the particular program. In the results section of this study, a comparison of how each program meets necessary topic coverage in supply chain management education is made. In some instances, slight modifications were made to the title of a course to keep it consistent with other courses in other programs.

\section{Name, Location And Degree}

The basic information collected from the ten universities shows that all the supply chain management programs are housed in the School or College of Business with only one exception - Purdue University - which has a School of Management. Only two programs have their own Department of Supply Chain Management, Arizona State University and Michigan State University. These two programs each have a much larger enrollment than any of the other programs; therefore, it is not unexpected that they are housed in their own department. There is no consistency in what department the program is housed for the remaining eight programs.

Only four of the ten programs are simply named Supply Chain Management. Two programs are named Operations Management, one is a combination of Operations and Supply Chain Management, one is named Logistics, one is a combination of Supply Chain Management and Logistics, and Carnegie Mellon University has entitled their program Manufacturing Management and Consulting. Six of the ten are considered a major by their corresponding university, while the remaining four are considered either "track" or "concentration". All graduating students earn a Bachelor of Science in Business Administration, with the exception of Michigan State University, which awards a Bachelor of Arts in Business Administration and Purdue University, which awards a Bachelor of Science in Management. This basic information is tabulated in Table 2 (see Appendix).

\section{The Common Core Business Courses}

Competency in mathematics, computer applications, and oral and written communication skills, while crucial to succeed in the program, are considered to have already been met and therefore are not included in this study.

All ten programs are semester-based and, in general, are 3-credit hour courses. There are no courses of more than 3-credit hours. In the few cases where courses are less than three hours, the decision was made that a 2hour course would be considered equivalent to a 3-hour course, a 1-hour course will not be considered, and a 1.5hour course would be combined with its continuation 1.5-hour second course (one case only) to form one 3-credit hour course. Any first accounting course will be considered as Accounting I and a second accounting course will be considered as Accounting II, regardless of the content or the teaching method.

A typical business degree core consists of the following 13 courses: two of economics (macroeconomics and microeconomics), two of accounting, and one of each statistics, law, information systems, finance, marketing, operations management, organization behavior management, international studies, and strategic management. Some 
of these tend to be more standardized (like accounting) than others (like international studies).

It appears there is little difference between the programs when it comes to the set of core courses. This is expected as all these programs are housed in an academic business unit that has to be accredited by the same national body. One program (Pennsylvania State University) has satisfied the core requirements with fewer than the usual number of courses but elected to offer the three omitted courses (accounting, international studies, and strategic management) among its course elective offerings, thus creating flexibility and opportunity for their students. Similarly, Ohio State University has its information systems course, and the University of Maryland has its operations management course, as part of their elective course offerings. Some programs have omitted a course or two from the typical business core, but given the nature of the topics covered in these omitted courses, it can be safely assumed that the subject matter is addressed in a combination of other courses. Table 3 (see Appendix) summarizes the business core for each of the ten programs.

\section{Required And Elective Courses}

It is in this part of the curriculum that each university capitalizes on its resources and relative strengths to build what it believes is the best program within its own constraints. As expected, it is in this part that major differences between the ten programs are obvious. Table 4 lists the required and elective courses for each program as well as the requirements for the elective courses. It is to be noted that each of these programs could have additional elective courses that are not related to the supply chain management discipline and are therefore outside the scope of this study.

It is interesting to note that only four of the ten programs have courses with a prefix of SCM for Supply Chain Management or LOG for Logistics. These programs are at Arizona State University, Michigan State University, Pennsylvania State University, and the University of Tennessee. Each of these programs are large enough to support courses that are dedicated solely to the program. The other six programs draw mainly from courses labeled with a management prefix.

The program at Arizona State University contains several courses of supply chain management plus a logistics course. It is enhanced by a quality management course and a negotiation course. A student can also take a course in business decision modeling as an elective. Started in 1998, the program at Arizona State University integrates globalization and information management tools effectively within its courses. With such basic course requirements, Arizona State University was able to grow this program's student body to one of the largest in the nation.

Carnegie Mellon University has only one course labeled as supply chain management and logistics in its set of required courses. Being known for its analytical inclination, students in its program are required to take mathematical modeling and system analysis and design. A quality techniques course is available as an elective together with a selection of analytical courses which include mathematics, decision analysis, decision support systems, forecasting, data mining, telecommunication and networks. The program looks quite suitable for students who are interested in consulting or working for a consulting firm.

Georgia Institute of Technology allows a high degree of flexibility. A management science course, which establishes the required minimum analytical foundation to all its students, is the only required course. Students will then have to select seven courses from a list of fourteen based on their interest and background. It is, however, apparently designed with a bottleneck that will not allow students to take courses of their own interest without satisfying a certain threshold level of courses in operations and supply chain management (see Table 4). Their program is heavy on operations efficiency and strategy as opposed to pure supply chain management.

Michigan State University, like the other large programs at Arizona State University, requires several courses in the different subspecialties of the supply chain management discipline, as well as a course in manufacturing planning and control. The requirement of two additional elective courses from a set of four gives its students more flexibility than their counterparts at Arizona State. This program at Michigan State, among the first in the nation, was born in 1997 by merging procurement, production, logistics, and marketing in one department. 
Table 4: Required And Elective Courses In Each Of The Ten Supply Chain Management Programs

\begin{tabular}{|c|c|c|}
\hline Arizona State U. & Michigan State U. & $\underline{\text { Rutgers U }}$ \\
\hline$\underline{\text { Required }}$ & $\underline{\text { Required }}$ & $\underline{\text { Required }}$ \\
\hline$\overline{\text { SCM } 345}$ Logistics Mgt & $\overline{\text { SCM } 303}$ Intro. to SCM & 799:301 Intro to SCM (core) \\
\hline SCM 355 Supply Mgt & SCM 371 Procurement \& SCM & 799:xxx Research Methods (core) \\
\hline SCM 432 SCM Planning \& Control & SCM 372 Manuf. Planning \& Control & 799:300 Global Proc \& Sourcing \\
\hline SCM 455 Research \& Negotiation & SCM 373 Logistics \& Transp. Mgt & 799:310 Demand Planning \& Fulfillment \\
\hline SCM 440 Quality Mgt & SCM 470 SC Application and Policy & 799:330 Bus Logistics \& Transportation \\
\hline SCM 479 SCM Strategy & Electives $(2 \mathrm{~min})$ & 630:385 Marketing Research \\
\hline Electives $(1 \mathrm{~min})$ & SCM 474 Negotiations & Plus 1 of the following 2 \\
\hline 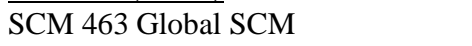 & SCM 475 Supply Chain Modeling & 630:369 New Product Planning \\
\hline SCM 315 Bus. Decision Models & SCM 476 Transportation Mgt & 799:380 Intro. to Project Mgt \\
\hline \multirow[t]{2}{*}{ Carnegie Mellon U. } & SCM 479 Adv. Topics in SCM & Electives (3 min) \\
\hline & Ohio State U. & 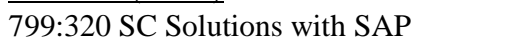 \\
\hline 70-453 System Analysis \& Design & \multirow{13}{*}{$\begin{array}{l}\text { Required } \\
\text { BUSML } 3380 \text { \& } 4380 \text { Logistics Mgt } \\
\text { BUSMGT } 4239 \text { Process Improvement } \\
\text { Mgt } \\
\text { BUSMGT } 4232 \text { Ops Planning \& Control } \\
\text { BUSMGT } 4250 \text { Six Sigma - Quality } \\
\text { Mgt } \\
\text { Electives (2 min) } \\
\text { BUSMGT } 4233 \text { Info Systems in Ops } \\
\text { BUSMGT } 4261 \text { Purchasing \& SCM } \\
\text { BUSMGT } 4262 \text { Purchasing Strategy } \\
\text { BUSMGT } 4237 \text { International Ops } \\
\text { BUSMGT } 4234 \text { Service Ops } \\
\text { BUSMGT } 4240 \text { Mgt of Technology } \\
\text { BUSMGT } 4383 \text { SCM }\end{array}$} & 799:410 Service Mgt \\
\hline 70-460 Mathematical Models & & 799:460 Intro to 6-sigma \& Lean \\
\hline 70-471 Logistics \& SCM & & 799:470 Bus Intelligence for SCM \\
\hline Plus 1 of the following 4 & & \multirow{11}{*}{$\begin{array}{l}\text { U. of Maryland } \\
\text { Required } \\
\text { BMGT } 370 \text { Intro to Transportation } \\
\text { BMGT 372 Intro to Logistics \& SCM } \\
\text { BMGT 476 Tech. Applications in SCM } \\
\text { Plus 2 of the following 6 } \\
\text { BMGT 373 SCM Internship } \\
\text { BMGT 470 Carrier Mgt } \\
\text { BMGT 471 Seminar in SCM } \\
\text { BMGT 472 Purch. \& Inbound Logistics } \\
\text { BMGT 475 SC Strategy \& Network } \\
\text { Design }\end{array}$} \\
\hline 21-365 Projects in Math & & \\
\hline 70-455 Info Resources Mgt & & \\
\hline $70-456$ Telecom and Networks & & \\
\hline 88-223 Decision Anal. and DSS & & \\
\hline Electives $(2 \mathrm{~min})$ & & \\
\hline Additional 2 of above 4 & & \\
\hline $\begin{array}{l}\text { or other courses } \\
\text { nof }\end{array}$ & & \\
\hline from a list that includes: & & \\
\hline 70-374 Forecasting \& Data Mining & & \\
\hline 70-474 Quality Princ. \& Techniques & \multirow{11}{*}{$\begin{array}{l}\quad \text { Pennsylvania State } \mathbf{U} . \\
\frac{\text { Required }}{\text { SCM } 301} \text { Business Logistics Mgt } \\
\text { SCM } 404 \text { Demand Fullfilment } \\
\text { SCM } 405 \text { Manuf \& Service Strategies } \\
\text { SCM 406 Strategic Procurement } \\
\text { SCM 421 Supply Chain Analytics } \\
\text { SCM 450W Design and Mgt of SC } \\
\text { Plus 12 Cr hr of a Foreign Lang } \\
\text { Electives (3 min) } \\
\text { Select from 24 non-SCM courses }\end{array}$} & \\
\hline Georgia Inst. of Tech. & & BMGT 477 International SCM \\
\hline Required & & Plus 1 of the following \\
\hline MGT 2251 Intro. To Mgt Science & & $\begin{array}{l}\text { BMGT } 302 \text { Developing Bus. } \\
\text { Applications }\end{array}$ \\
\hline Plus 6 courses as follows: & & BMGT 332 Ops Research for Mgt \\
\hline 4 to 6 of the following 7 & & $\begin{array}{l}\text { Decisions } \\
\text { BMGT } 385 \text { Ops Mgt }\end{array}$ \\
\hline 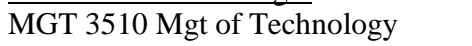 & & BMGT 455 Sales Mgt \\
\hline MGT 3744 Product/Service Design & & BMGT 482 Business \& Government \\
\hline MGT 4352 Ops Resource Planning & & BMGT 484 Electronic Marketing \\
\hline MGT 4353 Ops Strategy & & Electives $(1 \mathrm{~min})$ \\
\hline MGT 4360 Global Ops. \& SCM & & Plus 1 of any above \\
\hline MGT 4366 Service Operations & \multirow{12}{*}{$\begin{array}{l}\text { Purdue U. } \\
\text { Required: } 4 \text { courses of the following } 9 \\
\text { MGMT 45200 Manuf. Strategy } \\
\text { MGMT 46200 Manuf. Planning \& } \\
\text { Control } \\
\text { MGMT } 49002 \text { Logistics Concepts \& } \\
\text { Models } \\
\text { MGMT } 49004 \text { Spreadsheet Modeling } \\
\text { MGMT 56100 Logistics } \\
\text { MGMT 56200 Project Mgt } \\
\text { MGMT 56400 Mgt of Service Ops } \\
\text { MGMT 59001 Sourcing and Purchasing } \\
\text { MGMT 59002 Healthcare Supply } \\
\text { Chains }\end{array}$} & U. of Tennessee \\
\hline MGT 4803 Supply Chain Modeling & & Required \\
\hline 0 to 2 of the following 7 & & BUAD 331 SCM (core) \\
\hline MGT 3743 Emerging Tech & & BUAD 332 Demand Mgt (Core) \\
\hline MGT 4056 Electronic Commerce & & $\begin{array}{l}\text { BUAD } 353 \text { Integrated Process Mgt } \\
\text { (Core) }\end{array}$ \\
\hline MGT 4057 Process Anal. \& Design & & LOG 310 Intermediate Logistics \\
\hline MGT 4193 Leadership & & LOG 411 Logistics Analytical Methods I \\
\hline MGT 4309 Service Marketing & & $\begin{array}{l}\text { LOG } 412 \text { Logistics Analytical Methods } \\
\text { II OR }\end{array}$ \\
\hline MGT 4670 Entrepreneurship & & LOG 413 Logistics Ops Mgt \\
\hline MGT 4803 Mgt of Healthcare Ops & & LOG 421 Procurement \& Supply Mgt \\
\hline Electives (3 min) & & LOG 460 Strategic Logistics in Global \\
\hline & & \\
\hline
\end{tabular}


Ohio State University calls its major "Operations" and it actually shows on their course listing. Two of their five required courses are logistics and none is purely supply chain management. The remaining three are senior level operations courses. Their large electives offering is, however, well-balanced between operations and supply chain management; two additional elective requirements allow students to either continue their focus on operations or balance their knowledge with two courses of supply chain management.

Pennsylvania State University does not allow any flexibility with their set of supply chain management and logistics courses. All students have to take the same five courses plus a course in manufacturing and service strategies. Flexibility is allowed outside their specialty courses where students are allowed to choose their required twelve hours of foreign language and select their three elective courses from a list of twenty four courses not related to their specialty. This university's heavy weighing on foreign language is unique among the ten programs the authors studied.

Like Ohio State University, Purdue's balance tips to the side of operations. As it was previously noted, their degree is a Bachelor of Science in Management and their major is Operations Management with a concentration in Supply Chain and Logistics. After completing the core courses required for a management degree, students are required to take four courses from a list of nine, only two of which are logistics and one is sourcing and purchasing. The list also includes a specialty course in the field of healthcare supply chain. The remaining five courses are typical operations management courses.

Rutgers' program, with two required research courses, leans toward the consulting profession. The other four required courses cover the usual supply chain management topics like procurement, sourcing, demand planning and fulfillment, logistics, and transportation. Students are also required to take one course in either new product planning or project management. With an additional three out of four guided elective courses which include business intelligence, six-sigma and lean, supply chain solutions with SAP, and service management, students can acquire the necessary tools that prepare them to be productive soon after graduation.

The curriculum at the University of Maryland requires all students to take three courses - transportation, logistics and supply chain management, and technical applications in supply chain management. Each student must then take four courses from a list of twelve, allowing them some flexibility to specialize in a concentration of their choice. These twelve courses span a wide range of subjects all related to the field of operations and supply chain management.

The University of Tennessee is a logistics powerhouse and it is appropriate that they are the only university that names its major "Logistics". Their students are required to take supply chain management, demand management, and integrated process management courses as part of their business core, in addition to operations management. Their minimum requirement for majoring in logistics includes five additional courses in logistics and one in procurement and supply chain management. The five logistics courses are Intermediate Logistics, Logistics Analytical Methods I, Logistics Analytical Methods II, Logistics Operations Management, and Strategic Logistics in Global Supply Chain. Three other special logistics courses are also available for students in case they are interested in an off-campus experience, an independent study, or a special course in a field of interest to them.

\section{RESULTS}

This results section of the study consists of analysis and reporting on the content of the different supply chain management undergraduate courses at the ten selected universities. The study is limited to universities that have an undergraduate program as the intent is to look at how each university covers the supply chain management body of knowledge.

As previously stated, this research study attempts to discover a common approach for teaching this subject matter. Therefore, a super-set of course attributes was sought for comparative purposes. Forester (1961), as early as 1958, argued for the supply chain to be treated as an integrated system in his Harvard Business Review article "Industrial Dynamics: A Major Breakthrough for Decision Makers". It was not until almost 40 years later, during the 1995 Spring Informs meeting, that a panel of professors for the first time gathered to discuss the emerging 
interest in the integrated discipline of supply chain management. At that time, no complete program of supply chain management existed in any university and the few universities that taught supply chain management taught it as an individual course. Five years later, Johnson and Pyke (2000) researched the content of several courses and identified twelve categories which together form the integrated discipline of supply chain management. Radovilsky et al. (2007) and Sodhi et al. (2008) later derived subcategories based on the categories of Johnson and Pyke for use in their own research; nonetheless, Johnson and Pyke's categories remain the backbone of the supply chain management field. These twelve categories are:

1. Location and Supply Chain Design could include geographic information systems, country differences, transportation cost, location models, as well as taxes and duties if the location decision is global. All of these have an impact on the models, design and restructure. Qualitative, as well as quantitative, methods must be addressed.

2. Transportation and Logistics could include warehousing, transportation, material handling, dynamic management with satellite assisted information, and vehicle routing. Quantitative techniques, including optimization, could play a major role in this category.

3. Inventory and Forecasting: Harris's 100 year-old inventory model for the economic order quantity is not dead. In fact, there is an increased interest in inventory modeling and its extensions as managers see the cost of inventory accumulating while trying to optimize the cost in the supply chain. Of course, forecasting techniques play a critical role in the proper management of inventory.

4. Marketing and Channel Restructuring: This downstream foundation of the supply chain could cover channels management, relationship management, negotiation, pricing, promotion, vendor managed inventory and some legal aspects mostly related to anti-trust law.

5. Sourcing and Supplier Management: This upstream version of the supply chain deals with the suppliers and the management of the relationship with the supplier, whether a sole source supplier or a large number of suppliers in the case of competitive bidding. Global sourcing and make/buy decisions are also included in this category.

6. Information and Electronic Mediated Environment: The impact of MRP (Material Requirement Planning) on inventory management is well-documented. ERP (Enterprise Resources Planning) and CRM (Customer Service Management) - the daughter and granddaughter of ERP - are crucial elements in the supply chain. Business-to-business commerce and electronic channel retailing, like Amazon and E-Trade, are fully dependent on the electronic mediated environment. This dynamic and continuously changing category needs to be covered at a level that develops awareness to what is available and applicable for the field.

7. Product Design and New Product Introduction: New product introduction and product rollover, modular design, mass customization and delayed differentiation are among the topics covered within this category. The impact of these tactics on product cost and inventory savings must be considered.

8. Service and After-Sales Support: This category addresses the importance of the parallel channel of service before, during and after the sale. The flow and management of service parts contribute to how responsive an organization is to the needs of its customers.

9. Reverse Logistics and Green Issues: A relatively new dimension in supply chain is the efficient and environmentally friendly approach of dealing with product recovery and product returns. Consumer awareness and concern with regards to these issues justifiably continues to grow.

10. Outsourcing Organizational and Alliances: Several third party logistics providers continue to increase their role of adding value to the supply chain system. Supplier's hubs, including technical expertise at the facility of the logistics services provider, are not uncommon.

11. Metrics and Performance: Financial, productivity, and quality metrics are the performance measures management depends on for their daily decisions. Spreadsheet competency provides an important tool for analysis and decision-making.

12. Global Issues: Exchange rates, currency stability, customs, taxes, duties, government incentives, government regulations and cultural differences are among the issues that need to be addressed when covering this last category of global issues.

The authors analyzed the course description and, when available, the syllabus of each of the supply chain management courses listed in the program of each of the ten universities. Based on the course description and the syllabus, they judged on which of the categories spans over a serious part (fifteen percent or more) of the course. 
Table 5 (see Appendix) shows the course where each of the twelve categories is covered for all the universities in this study.

The authors recognize the fact that different professors cover the same subject at different levels or depth and therefore acknowledge that the tabulated results are as accurate as the analysis of the course description or syllabus and mirror the typical expected variance in course coverage. It is important to note that a vacant cell in the table does not necessarily represent that the subject matter is not covered; it could mean the subject matter is covered in several courses without dedicating more than fifteen percent of a course to it. It could also mean that this category is covered in a course from outside the department, like engineering. In some cases, it could mean that the university has a focus on some categories at the expense of others.

\section{CONCLUSION}

A relatively newcomer to business education, the field of supply chain management is still in its formation stage. Different universities treat the discipline and its pertaining body of knowledge in different manners. Very little research work has been done on the undergraduate curriculum and therefore universities took the liberty of creating the program that best fits their resources and strengths. This study tried to create a structured template using ten leading universities in the field as boilerplate. Universities revising their undergraduate program of supply chain management, or establishing a new program, can use these results to help them decide on designing one of their own. Practitioners can also use the results to help them capture what is being covered in the classrooms and behind the "academic walls". One thing is certain - that supply chain management, like any other management discipline, will always lack complete structure and therefore different universities will always have some differences in the way they address this major or design their curricula.

\section{AUTHOR INFORMATION}

Saba Bahouth is Professor of Operations Management in the College of Business at the University of Central Oklahoma. He holds a BE in mechanical engineering, a MS in management of engineering and a Ph.D. in industrial engineering. He started and managed the university's partnership with the Oklahoma City Air Logistics Center Tinker AFB over the past fourteen years, helping the center fill their need for operations and supply chain professionals. He has published in the International Journal of Production Research, Psychological Reports, Industrial Management and Data Systems, and others. Prior to academia, Dr. Bahouth worked for oil and gas companies. E-mail: sbahouth@uco.edu (Corresponding author)

David Hartmann is an Associate Professor of Operations Management in the College of Business at the University of Central Oklahoma where he teaches MBA and undergraduate courses in operations and supply chain management and quantitative modeling. He holds a BS degree from the United States Air Force Academy, a MS degree in logistics management from the Air Force Institute of Technology, a MBA degree from the College of William and Mary in Virginia, and a Ph.D. degree in industrial engineering from Oklahoma State University. In 2012, Dr. Hartmann completed a Fulbright at the University of Business and Technology, Jeddah, Saudi Arabia. E-mail: dhartmann@uco.edu

Geoff Willis is a professor of Operations Management in the College of Business at the University of Central Oklahoma where he teaches MBA and undergraduate courses in operations management and quantitative methods. He holds BS degrees in biomedical engineering and mathematics from Vanderbilt University and MS and Ph.D. degrees in production and operations management from Texas Tech University. He has published in The Journal of Operations Management, International Journal of Production Research, The Journal of Safety Research, Quality Engineering, and others. Prior to his academic career, Dr. Willis worked as a consultant in the healthcare and computer industries. E-mail: gwillis@uco.edu

\section{REFERENCES}

1. Berry, S. E. \& Lancaster, L. M. (1992). Views of production practitioners on the importance of selected POM topics: 1978 and 1989 practitioners compared. Production and Inventory Management Journal, Vol. 
33(2), pp. 24-31.

2. Clayson, D. E. \& Haley, D. A. (2005). Marketing models in education: students as customers, products, or partners. Marketing Education Review, Vol. 15(1), pp. 1-10.

3. Closs, D. J. \& Stank, T. P. (1999). A cross-functional curriculum for supply chain education at Michigan State University. Journal of Business Logistics, Vol. 20(1), pp. 59-72.

4. Corsi, T., Boyson, S., Verbraeck, A., Van Houten, S., Han, C. \& Macdonald, J. (2006). The Real-Time Global Supply Chain Game: New Educational Tool for Developing Supply Chain Management Professionals. Transportation Journal (American Society of Transportation \& Logistics Inc), Vol 45(3), pp. 61-73.

5. $\quad$ Creveld, M. V. (1977). Supplying War: Logistics from Wallenstein to Patton. Boston, MA.: Cambridge: Cambridge University Press.

6. Croom, S., Romano, P. \& Giannakis, M. (2000). Supply Chain Management: An analytical framework for critical literature review. European Journal of Purchasing and Supply Management, Vol 6(1), pp. 67-83.

7. Davis, E. W. (1975). A look at the use of production-inventory techniques: past and present. Production and Inventory Management Journal, Vol. 16(4), pp. 1-19.

8. Davis, E. W. (1974). State of the art survey: a preliminary analysis. Production and Inventory Management Journal, Vol. 15(4), pp. 1-11.

9. Ferrin, B. G., Landeros, R. \&Reck, R. F. (2001). Integrated supply matrix management: A TQM approach for curriculum development. International Journal of Physical Distribution \& Logistics Management, Vol. 31(7/8), pp.520-537.

10. Fleming, D. L. (2008). Building Bridges to connect the disconnects: An analysis of business program design processes. American Journal of Business Education, Vol. 1(2).

11. Forrester, J. (1961). Industrial Dynamics. Wiley, New York.

12. Gonzalez, M., Quesada, G., Gourdin, K. \& Harley M (2008). Designing a supply chain management academic curriculum using QFD and benchmarking. Quality Assurance in Education, Vol. 16(1), pp. 36-60.

13. Green, T. B., Newsom, W. B. \& Jones, S. R. (1977). A survey of the application of quantitative techniques to production/operations management in large corporations. Academy of Management Journal, Vol. 20(4), pp. 669-676.

14. Heckert, J. B. \& Miner, R. B. (1940). Distribution Costs. New York, NY: The Ronald Press Company.

15. Hegde, V. \& Radovilsky, Z. (2012). Shift in Supply Chain Job Requirements and its impact on supply chain management curriculum. Journal Of The Academy Of Business \& Economics, Vol. 12(4), pp. 28-38.

16. Huynh, M. \& Chu, H. (2011). Open-Source ERP: Is It Ripe for Use in Teaching Supply Chain Management? Journal of Information Technology Education, Vol. 10.

17. Hwarng, B. \& Teo, C. (2001). Translating customers' voices into operations requirements: a QFD application in higher education”. International Journal of Quality and Reliability Management, Vol. 18(2), pp. 195-225.

18. Johnson, M. E. \& Pyke, D. F. (2000). A framework for teaching supply chain management. Production and Operations Management Journal, Vol. 9(1), pp. 2-18.

19. Larson, P. (2008). Accreditation program design: a survey of supply chain professionals. Journal of Enterprise Information Management, Vol. 21(4), pp. 377-392.

20. Lewis, H. T. (1956). The Role of Air Freight in Physical Distribution. Boston, MA: Graduate School of Business Administration, Division of Research at Harvard University.

21. Mabert, V. A. \& Showalter, M. J. (2010). Logistics of the American Circus: the Golden Age. Production and Inventory Management Journal, Vol. 46(1), pp. 74-90.

22. Melnyk, S. A., Stank, T. P. \& Closs, D. J. (2000). Supply chain management at Michigan State University: the jouney and the lessons learned. Production and inventory Management Journal, Vol. 41(3), pp. 13-18.

23. Morris, J. S. (1997). A new approach to teaching production operations management in the business core curriculum. Production and Inventory Management Journal, Vol. 38(2), pp. 42-46.

24. Ozment, J. K. (2011). The future of logistic education. Transportation Journal, Vol. 50(1), pp. 65.

25. Radovilsky, Z., Hegde, V. G. \& Kandasamy, G. (2007). Development of Supply Chain Management through Job Market Requirements. California Journal of Operations Management, Vol. 5(1), pp. 52-59.

26. Sodhi, M. S., Son, B. G., \& Taang, C., S. (2008). ASP, The Art and Science of Practice: What Employers Demand from Applicants for MBA-Level Supply Chain Jobs and the Coverage of Supply Chain Topics in MBA Courses. Informs. Vol. 38(6), pp. 469-484. 
27. Sterman, J. D. (1989). Modeling Managerial Behavior: Misperceptions of Feedback in a Dynamic Decision Making Experiment. Management Science, Vol. 35(3), pp. 321-339.

28. Visich, J. (2006). Operations Management curricula: literature review and analysis. Journal of Statistics and Management Systems, Vol. 9(3), pp. 661-687.

29. Visich, J. \& Khumawala, B. (2006). Operations Management curricula: literature review and analysis. Journal of Statistics and Management Systems, Vol. 9(3), pp. 661-687.

30. Vollmann, T. E., Cordon, C. \& Heikkila, J. (2000). Teaching supply chain management to business executives. Production and Operations Management Journal, Vol. 9(1), pp. 81-90.

31. Wild, R. (1984). Survey report: the responsibilities and activities of UK production managers. International Journal of Operations and Production Management, Vol. 4(1), pp. 69-74. 


\section{APPENDIX}

Table 2: Basic Information On The Ten Supply Chain Management Programs

\begin{tabular}{|c|c|c|c|c|c|c|c|}
\hline University & City, State & Name & College/School & Under Unit & Name of Program & Referred to as & Degree \\
\hline Arizona State U. & Tempe, AZ & $\begin{array}{l}\text { W.P. } \\
\text { Carey }\end{array}$ & School of Business & Dept. of SCM & Supply Chain Mgt & Major & $\begin{array}{l}\text { BS in Bus } \\
\text { Adm }\end{array}$ \\
\hline Carnegie Mellon U. & Pittsburg, PA & Tepper & School of Business & School of Business & $\begin{array}{l}\text { Manuf. Mgt \& } \\
\text { Consulting }\end{array}$ & Track & $\begin{array}{l}\text { BS in Bus } \\
\text { Adm }\end{array}$ \\
\hline $\begin{array}{l}\text { Georgia Inst. of } \\
\text { Tech. }\end{array}$ & Atlanta, GA & - & School of Business & College of Management & $\begin{array}{c}\text { Ops \& Supply Chain } \\
\text { Mgt }\end{array}$ & Concentration & $\begin{array}{l}\text { BS in Bus } \\
\text { Adm }\end{array}$ \\
\hline Michigan State U. & East Lansing, MI & Broad & College of Business & Dept of SCM & Supply Chain Mgt & Major & $\begin{array}{l}\text { BA in Bus } \\
\text { Adm }\end{array}$ \\
\hline Ohio State U. & Columbus, $\mathrm{OH}$ & Fisher & College of Business & College of Business & Operations & $\begin{array}{l}\text { Specialty / } \\
\text { Track }\end{array}$ & $\begin{array}{l}\text { BS in Bus } \\
\text { Adm }\end{array}$ \\
\hline $\begin{array}{c}\text { Pennsylvania State } \\
\text { U. }\end{array}$ & $\begin{array}{c}\text { University Park, } \\
\text { PA }\end{array}$ & Smeal & College of Business & Dept of SC\&IS & Supply Chain Mgt & Major & $\begin{array}{l}\text { BS in Bus } \\
\text { Adm }\end{array}$ \\
\hline Purdue U. & $\begin{array}{l}\text { West Lafayette, } \\
\text { IN }\end{array}$ & Krannert & School of Management & School of Management & $\begin{array}{c}\text { Ops Mgt } \\
\text { (SC/Logistics) } \\
\end{array}$ & Concentration & $\mathrm{BS}$ in $\mathrm{Mgt}$ \\
\hline Rutgers U. & $\mathrm{NJ}+$ & - & School of Business & $\begin{array}{c}\text { Dept of SCM \& Marketing } \\
\text { Science }\end{array}$ & $\begin{array}{c}\text { SCM/Logistics \& SC } \\
\text { Tech }\end{array}$ & Major / Track & $\begin{array}{l}\text { BS in Bus } \\
\text { Adm }\end{array}$ \\
\hline U. of Maryland & College Park, MD & R. Smith & School of Business & $\begin{array}{c}\text { Logistics, business and PP } \\
\text { Dept }\end{array}$ & Supply Chain Mgt & Major & $\begin{array}{l}\text { BS in Bus } \\
\text { Adm }\end{array}$ \\
\hline U. of Tennessee & Knoxville, TN & - & College of Business & Dept of Marketing \& SCM & Logistics & Major & $\begin{array}{l}\text { BS in Bus } \\
\text { Adm }\end{array}$ \\
\hline
\end{tabular}

+ New Brunswick campus and Newark campus 
Table 3: Required Business Core In Each Of The Ten Supply Chain Management Programs

\begin{tabular}{|c|c|c|c|c|c|c|c|c|c|c|}
\hline & 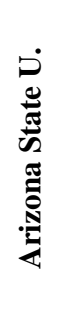 & 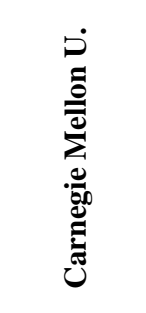 & 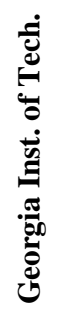 & 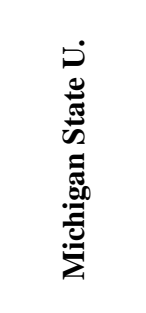 & 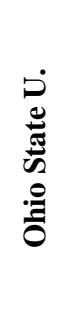 & 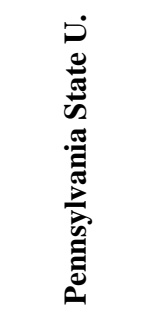 & 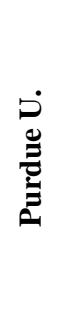 & 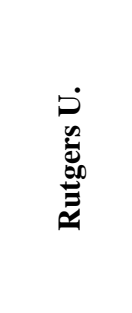 & 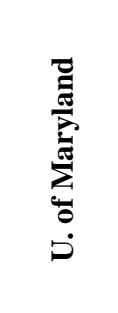 & 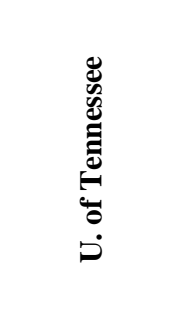 \\
\hline Macroeconomics & $\mathrm{Y}$ & $\mathrm{Y}$ & $\mathrm{Y}$ & $\mathrm{Y}$ & $\mathrm{Y}$ & $\mathrm{Y}$ & $\mathrm{Y}$ & $\mathrm{Y}$ & $\mathrm{Y}$ & $\mathrm{O}$ \\
\hline Microeconomics & $\mathrm{Y}$ & $\mathrm{Y}$ & $\mathrm{Y}$ & $\mathrm{Y}$ & $\mathrm{Y}$ & $\mathrm{Y}$ & $\mathrm{Y}$ & $\mathrm{Y}$ & $\mathrm{Y}$ & $\mathrm{Y}$ \\
\hline Business Statistics & $\mathrm{Y}$ & $\mathrm{Y}$ & $\mathrm{Y}$ & $\mathrm{Y}$ & $\mathrm{Y}$ & $\mathrm{Y}$ & $\mathrm{Y}$ & $\mathrm{Y}$ & $\mathrm{Y}$ & $\mathrm{Y}$ \\
\hline Business Law & $\mathrm{Y}$ & $\mathrm{Y}$ (Ethics) & $\mathrm{Y}$ & $\mathrm{O}$ & $\mathrm{Y}$ & $\mathrm{Y}$ & $\mathrm{Y}$ & $\mathrm{Y}$ & $\mathrm{Y}$ & $\mathrm{Y}$ \\
\hline Accounting 1 & $\mathrm{Y}$ & $\mathrm{Y}$ & $\mathrm{Y}$ & $\mathrm{Y}$ & $\mathrm{Y}$ & $\mathrm{Y}$ & $\mathrm{Y}$ & $\mathrm{Y}$ & $\mathrm{Y}$ & $\mathrm{Y}$ \\
\hline Accounting 2 & $\mathrm{Y}$ & $\mathrm{O}$ & $\mathrm{Y}$ & $\mathrm{Y}$ & $\mathrm{Y}$ & $\mathrm{E}$ & $\mathrm{Y}$ & $\mathrm{Y}$ & $\mathrm{Y}$ & $\mathrm{O}$ \\
\hline Information Systems & $\mathrm{O}$ & $\mathrm{Y}$ & $\mathrm{Y}$ & $\mathrm{Y}$ & $\mathrm{E}$ & $\mathrm{Y}$ & $\mathrm{Y}$ & $\mathrm{Y}$ & $\mathrm{Y}$ & $\mathrm{Y}$ \\
\hline Finance & $\mathrm{Y}$ & $\mathrm{Y}$ & $\mathrm{Y}$ & $\mathrm{Y}$ & $\mathrm{Y}$ & $\mathrm{Y}$ & $\mathrm{Y}$ & $\mathrm{Y}$ & $\mathrm{Y}$ & $\mathrm{Y}$ \\
\hline Marketing & $\mathrm{Y}$ & $\mathrm{Y}$ & $\mathrm{Y}$ & $\mathrm{Y}$ & $\mathrm{Y}$ & $\mathrm{Y}$ & $\mathrm{Y}$ & $\mathrm{Y}$ & $\mathrm{Y}$ & Y (Demand) \\
\hline Operations Management & $\mathrm{Y}$ & $\mathrm{Y}$ & $\mathrm{Y}$ & $\mathrm{Y}(\mathrm{SCM})$ & $\mathrm{Y}$ & $\mathrm{Y}(\mathrm{SCM})$ & $\mathrm{Y}$ & $\begin{array}{c}\mathrm{Y} \\
\text { (Product) }\end{array}$ & E & $\mathrm{Y}$ \\
\hline $\begin{array}{c}\text { Organization Behavior / } \\
\text { Management }\end{array}$ & $\mathrm{Y}$ & $\mathrm{Y}$ & $\mathrm{Y}$ & $\mathrm{Y}$ & $\mathrm{Y}$ & $\mathrm{Y}$ & $\mathrm{Y}$ & Y & $\mathrm{Y}$ & $\mathrm{Y}$ \\
\hline International & $\mathrm{Y}$ & $\mathrm{Y}$ & $\mathrm{Y}$ & $\mathrm{Y}$ & $\mathrm{Y}$ & $\mathrm{E}$ & $\mathrm{Y}$ & $\mathrm{Y}$ & $\mathrm{O}$ & $\mathrm{Y}$ \\
\hline Strategic Management & $\mathrm{O}$ & Y (Game) & $\mathrm{Y}$ & $\mathrm{Y}$ & $\mathrm{Y}$ & E & $Y$ & $Y$ & $\begin{array}{c}\mathrm{Y} \\
\text { (Policy) }\end{array}$ & $\mathrm{Y}$ \\
\hline
\end{tabular}

$\mathrm{Y}=$ Course required in the business core. $\mathrm{E}=$ Course is an option as elective in the program. $\mathrm{O}=$ Course is not part of the program. 


\begin{tabular}{|c|c|c|c|c|c|c|}
\hline & Supply Chain Categories/Topics & Arizona State U. & Carnegie Mellon U. & $\begin{array}{c}\text { Georgia Inst. of } \\
\text { Tech. }\end{array}$ & Michigan State U. & Ohio State U. \\
\hline $\mathbf{A}$ & Location and Supply Chain Design & $345,432,463$ & 453,471 & 4353 & 373,475 & $4239,4233,4383$ \\
\hline B & Transportation and Logistics & $345,479,463$ & 471 & 4353 & 373,475 & 3380,4380 \\
\hline $\mathbf{C}$ & Inventory and Forecasting & 345,432 & 471,374 & 4352 & $372,373,475$ & 4232 \\
\hline D & Marketing and Channels Restructuring & 345,355 & & & & \\
\hline $\mathbf{E}$ & Sourcing and Supplier Management & $355,455,479,440$ & & 4353,4360 & $371,474,479$ & 4261,4262 \\
\hline $\mathbf{F}$ & Information and Electronic Mediated Env. & 432,479 & $455,456,374,88-374$ & 3510,4056 & 479 & 4233 \\
\hline $\mathbf{G}$ & Product Design and New Product Intro. & 479 & & 3744 & & 4240 \\
\hline $\mathbf{H}$ & Service and After-Sale Support & 345 & & 4366 & & 4234 \\
\hline $\mathbf{I}$ & Reverse Logistics and Green Issues & 345 & 471 & 4353,4360 & 373,479 & 3380,4380 \\
\hline $\mathbf{J}$ & Outsourcing Organizational and Alliances & 463 & & $4353,4360,4366$ & 371,479 & 4261,4262 \\
\hline $\mathbf{K}$ & Metrics and Performance & 440 & 474 & $\begin{array}{c}4057,4352,4353, \\
4803\end{array}$ & 475,479 & 4232,4250 \\
\hline $\mathbf{L}$ & Global Issues & 463 & & 4353,4360 & 470 & 4237 \\
\hline & & Penn State U. & Purdue U. & Rutgers U. & U. of Maryland & U. of Tennessee \\
\hline $\mathbf{A}$ & Location and Supply Chain Design & 405 & 561 & 301 & $370,372,476,475,477$ & $412,421,460$ \\
\hline B & Transportation and Logistics & 404 & 561 & 301,330 & $370,372,470,472,477$ & $310,411,412,413,460$ \\
\hline $\mathbf{C}$ & Inventory and Forecasting & 404 & 49002,561 & 310 & $372,472,477$ & 310 \\
\hline $\mathbf{D}$ & Marketing and Channels Restructuring & 404 & 452 & $301,310,385$ & 477 & 310 \\
\hline $\mathbf{E}$ & Sourcing and Supplier Management & 405,406 & 452,59001 & 300,301 & $370,472,477$ & 413,421 \\
\hline $\mathbf{F}$ & Information and Electronic Mediated Env. & $404,405,406$ & $462,49002,49004,562$ & $301,320,470$ & 476,475 & \\
\hline $\mathbf{G}$ & Product Design and New Product Intro. & 406 & 452,562 & 369 & & \\
\hline $\mathbf{H}$ & Service and After-Sale Support & 405 & 452,564 & 410 & 477 & 310 \\
\hline I & Reverse Logistics and Green Issues & & 561 & 330 & $370,372,470,472,477$ & $310,411,412,413,460$ \\
\hline $\mathbf{J}$ & Outsourcing Organizational and Alliances & 405,406 & 59001 & 300,301 & & \\
\hline $\mathbf{K}$ & Metrics and Performance & $404,405,421$ & 462 & 460,470 & 476 & $411,412,421$ \\
\hline $\mathbf{L}$ & Global Issues & $404,405,406,450 \mathrm{~W}$ & 59001 & 300 & 477 & $310,411,412,421,460$ \\
\hline
\end{tabular}

The number in the table is a course number (refer to Table 3 for course titles). 